\title{
Informal land registration under unclear property rights: witnessing contracts, redevelopment, and conferring property rights
}

\author{
Authors \\ Prof. Lawrence W.C. Lai ${ }^{1,2,4}$, \\ wclai@hku.hk \\ Prof. Frank T. Lorne ${ }^{1,3}$ \\ florne@nyit.edu \\ Chair Prof. PK.W. Chau ${ }^{1,2}$ \\ hrrbckw@hku.hk \\ Ken S.T. Ching 5 \\ kenching@ netvigator.com
}

\author{
${ }^{1}$ Ronald Coase Centre for Property Rights Research \\ ${ }^{2}$ Department of Real Estate and Construction, University of Hong Kong \\ ${ }^{3}$ School of Management, New York Institute of Technology, Vancouver \\ ${ }^{4}$ Registered Professional Planner/Corresponding author \\ ${ }^{5}$ Registered Professional Surveyor (Land Surveying)
}

8 September 2015

Preprint version

Forthcoming in

\section{Land Use Policy}

\section{Suggested citation:}

Lai, L. W. C., Lorne, F. T. and Chau, K. W., Ching, K. S. T. (forthcoming). Informal land registration under unclear property rights: witnessing contracts, redevelopment, and conferring property rights. Land Use Policy, forthcoming. 


\title{
Informal land registration under unclear property rights: witnessing contracts, redevelopment, and conferring property rights
}

\begin{abstract}
$\underline{\text { Abstract }}$
The significance of informal land registration in property transactions and development has been discussed at length, but there are few examples of in-depth case studies of how this information accessing and collection institution relates to them and how it may create property rights. This paper examines the nature and operation of non-governmental and voluntary land transaction registration practices in Kowloon Walled City, an ideal example of a privately-planned and developed habitat under unclear property rights due to jurisdictional disputes between China and Britain and no state protection of property rights or intervention in building control existed. Based on documentary evidence interpreted from a Coasian and Hayekian stance, it advances the proposition that the contracts the Kowloon Walled City Kaifong Welfare Promotion Association (hereafter the Kaifong Association) sought to represent as a witness built up its political credibility as a representative body. Such a role not only reduced transaction costs of contract enforcement and, hence, facilitated redevelopment, but also became that of a quasi-government land registrar due to the popularity of its witnessing service, which, under specific circumstances, served as the basis for the assignment of de jure private property rights by the state.
\end{abstract}

It was a good example of Hong Kong people ruling Hong Kong

(Jones 2011: p.270, quoting Xu Jiatun, Head of the Xinhua News Agency)

\section{Keywords}

Witness, land contract, informal land registration, unclear property rights, transaction cost 


\section{$\underline{\text { Introduction }}$}

How a body emerges as a political representative for a group of individuals, protects them from collective threats, and enables them to capture collective benefits is a key question for the political economist. As a contribution to this question from a property rights angle, this paper demonstrates that the competence of a squatter association in protecting the interests of its members squatting in a de facto un-governed area within a powerful state could be derived from its transaction cost reduction service in witnessing land transactions not recognized by that state. As a witness, the association became a quasi-government land registrar due to its popularity, and this, under specific historical circumstances, served as the basis for the assignment of de jure private property rights by the state.

Based on information in confidential government files that were released after 1997, denied to (or withheld by) researchers in the past ${ }^{1}$, and have hitherto been ignored by scholars, and samples of land transaction records of property units kept by the Kaifong Association and revealed to the authors, this interdisciplinary study, informed by Coasian transaction cost concepts and land surveying techniques, illustrates a theoretical conjecture that information generates rights when the economic significance of the market shifts from individual transactions to the information witnessed, if not also to the witnessing body itself. This conjecture was developed on the thesis of Cheung $(1974$; 2014), who argued that rent dissipation is a transaction cost that would be institutionally constrained by rational individuals seeking protection. Evidence of a minimization of rent dissipation based on an analysis of the physical conditions and boundaries of redevelopment within the Kowloon Walled City (KWC) was adduced to support this conjecture

\section{Theoretical background}

The significance of informal land registration in property transactions and development has been discussed at length (see, for instance, Wanjohi 2007; Benjaminsen et al. 2009; MeinzenDick et al 2008; Greiber 2011; Manirakiza 2014) but there are few examples of in-depth case studies of how this information accessing and collection institution relates to them and how it may create property rights. There is also a huge and looming amount of literature on the significance of witnesses in informal land transactions, i.e. transactions not according to formal law or state rules. From early times, legal systems, formal or otherwise, required witnesses to

\footnotetext{
1 Jones (2011), for instance, did not disclose what confidential materials he got in Touch as a District Officer due to conflict of interest. Bristow's (1984) classic work on local land-use planning covered pre-war planning for the KWC, but was constrained by data access to post-war confidential files. When Wesley-Smith researched for his 1973 paper and approached government, he was not given confidential or secret information.
} 
properly carry out title transactions (Arrunada 2003). Evidence for this is present in the Holy Scriptures (Chianu 1992). Bearing witness was often made in writing or through other forms of monument like stones (Strathern, and Stewart 1998).

The significance of witnesses in customary or non-governmental land transactions has been well-documented in many African and Asian countries such as Nigeria (Nwogugu 1964; Chianu 1992); Kenya (Mackenzie 1996; Musembi 2007); Rwanda (André and Platteau 1998); Ghana (Gough and Yankson 2000; Blocher 2006; Abdulai and Hammond 2010; Abdulai and Owusu-Ansah 2014); Francophone Rural Africa (Delville 2002); Uganda (Nkurunziza 2007); Sub-Sahara Africa (Toulmin, 2009); Tanzania (Parsa et al 2011); Ethiopia (Bezu and Holden 2014); South East Asia (Fandl 2005); the Philippines (Innes 1918); Imperial China (Rawski 1972; Hase 2013; Fung 2014; Lai et al. 2015); Indonesia (Brown 2003); Papua New Guinea (Strathern, and Stewart 1998; Koczberski, Curry, and Anjen 2012); Sri Lanka (Perera 2011); Benin (Yemadje et al. 2012); Nepal (Chhetri 2014).

Often witnesses are considered more significant than the content of any written document (Delville 2002) and invariably trusted individuals, notably community leaders (Zevenbergen et al. 2013). In economic theory, the significance of witnesses in enforcing contracts in the absence of state involvement (Caplan 1997; Rubin 1994) can be articulated in terms of what Friedman (2005) called "reputational enforcement".

However, witnessing as a part of an informal institutional process not only to reduce transaction costs, but also to obtain property rights, is an unexplored line of inquiry this paper attempts to explore.

\section{$\underline{\text { Historical context }}$}

All land in Hong Kong is government land and treated as British Crown land before 1 July 1997. The state has always enjoyed enormous power in its ability to dictate private land use and built forms by means of government leases and various ordinances that can modify these leases (Lai 1996; 1998, Lai et al. 2010). The case of the KWC, which was called "The City of Darkness" by Popham (1993) and seconded by Girard et al. (1999), was an embarrassing exception. The KWC was a post-war high-density, high-rise urban jungle with a maximum population of about 30,000 people. $^{2}$ It was built up by Hong Kong Chinese builders and occupied by Hong Kong citizens, whom the British Colonial Hong Kong Government categorized as squatters, within the

\footnotetext{
2 Jones (2011: p.275) gave a 1987 figure of 33,000 persons.
} 
perimeters of the proper $^{3}$ of an Imperial Chinese fort with an area of approximately 2.6 hectares built since the mid- $19^{\text {th }}$ Century, after which successive Chinese Governments claimed complete sovereignty.

The dispute over sovereignty arose because in the Peking Convention of June 1898 regarding the lease of the New Territories to Britain, ${ }^{4}$ China had the right to station officials in the fort insofar as they posed no military threat to Hong Kong. But all Imperial Chinese officials were expelled for questionable reasons by the Hong Kong Government in May 1899 soon after the lease took effect in July 1898.

The international treaty was interesting. The term, "leasing," was used, but no rent was spelled out and Britain paid no rent. Furthermore, it was not accompanied by a plan of the fort, which was simply roughly positioned as a square on a very small-scaled map.

After the Chinese officials were expelled, the Hong Kong Government conducted a cadastral survey (called "Indian survey" as surveyors and technicians were from British India) of the fort as part of a comprehensive land survey of the New Territories to produce a set of Demarcation District maps to accompany the "Block Crown Leases".

It took the colonial government over 40 years until the eve of the Battle of Hong Kong to completely clear the Chinese civilians inside the fort, which it regarded as squatters after short terms leases to original inhabitants expired, in the hope of turning it into a public garden. The boundaries of the lots under leases were based on actual possession as at the date of the Indian survey and can be found on a 1909 Demarcation District map or a "SD sheet". The Japanese, who captured Hong Kong on Christmas Day 1941, demolished all of the KWC's defensive stone walls to expand the Kai Tak Airport. Chinese residents began to build houses in the KWC once more during the Japanese occupation and 1945 RAF aerial photos of Hong Kong clearly showed that the whole City and its vicinity were inhabited.

Since then until 1963, sporadic attempts by the colonial administration to enter the fort area to clear its ever-increasing number of residents in order to transform it from a slum into a park failed under diplomatic pressure by China. The 1963 attempt fostered the emergence of a new institution, the Kaifong Association. "Kaifong" means "residents in a neighbourhood".

3 Though mentioned in Chinese documents of the mid-19th Century and shown in a Hong Kong Government Demarcation District map, most scholars and government authorities have ignored the outer perimeters. See Lai (2015). This was called "Area D" in the so-called Nunnery Scheme. See Minute 6 in Colonial Secretary (1976). "Kowloon Walled City: Implementation of Ad Hoc Committee Reports," Confidential File CR5/3371/60 Part VII. [HKRS 163-9-233 Part I]. This document could only be released on or after 2 February 2003 under the thirty-year rule.

4 Jones (2011: p.265). 
Like all developers who built and sold properties in the $\mathrm{KWC}$, the Kaifong Association always held that its land was "Chinese territory" and, thus, free from the control of the colonial administration. The latter was alerted by the high-rise transformation of the KWC, but resolved to turn a "close eye" 5 towards development and redevelopment within the confines of the original walls of the proper of the fort unless the buildings exceeded the height limit, which would interfere with the air traffic of Kai Tak Airport (City District Officer (Kowloon City) 1975b, Lai 2015).

A Kaifong Association is a club with leaders elected by residents, but it is not a statutory body or political party seeking to appoint leaders to participate in any form of local government, which did not exist in Hong Kong up to the 1970s. Before popularly-elected district Boards (District Councils after 1997) were introduced in 1981 as a formal channel of public consultation, the colonial government informally consulted the leaders of the Kaifong Associations to gather the public opinions of "grassroots" Chinese people in the absence of democratic political mediation (Miners 1981; Lau 1981; Hayes and Hayes 1983; Degolyer and Scott 1996). The Kaifong Associations have their equivalents in other Chinese settlements like Macau (Lo 1996) and Chinatowns overseas (Wong 1971). As a club, membership in the Kaifong Associations is voluntary, cross-cultural, and relatively non-exclusive without discrimination on the basis of dialect or hometown origin, as stressed in hometown associations. Subscription is often voluntary and payment often according to means. The typical services a Kaifong Association offers are organizing festivals (especially during Chinese New Year and the Mid-autumn Festival, which also include public entertainment, notably Cantonese opera and Drag/Lion dances). Generally, it is non-militant and not high-profile and provides a useful bridge between residents and the government when formal political articulation is absent or avoided. Unlike modern resident associations in Hong Kong or elsewhere, which are invariably formally established by contract and also legally regulated (Lai and Chan 2004, Glasze 2005; Manzi and Smith-Bowers 2005; Yau 2013), Kaifong associations are clubs which are non-exclusive. This type of club in neo-institutional economics has been an under-researched area. In any event, a club can be a means to promote solidarity by bringing a community together, doing something together, educating members on certain issues, advancing society in some way, and training its members (Kingston 2013).

\footnotetext{
5 A serious "short study" was made in 1972, after Britain fully recognized the Chinese Communist Government as legitimate in 1971. It listed ten active developers and their backgrounds. See City District Officer (Kowloon City) (1972). "A Short Study on Multi Storey Buildings in and Around the Walled City." Confidential report dated 7.11.1972 in Colonial Secretary (1976). Minute 6 in file, "Kowloon Walled City: Implementation of Ad Hoc Committee Reports." Confidential File CR5/3371/60 Part VII. Part II. [HKRS 163-9-233 Part II] refers to this closeeyed policy. This document could only be released on or after 2 February 2003 under the thirty-year rule.
} 
Due to its peculiar constitutional status, the colonial administration did not interfere with building development and redevelopment inside the fort or apply the laws concerning industries or town planning to this special place. It did provide a postal service and police patrols, but no garbage collection service, sewerage or portable water reticulation. The dwellings inside the KWC were never dark or cut off, as the franchised public utilities company duly supplied its residents with electricity and telephone services. The movement of citizens in and out of the KWC was un-regulated.

From the late 1960s onwards, rapid growth in demand for housing and industrial employment in Hong Kong transformed the KWC from a two-storey shantytown into an eight to 13-storey densely-packed urban habitat almost directly above which huge aeroplanes made their sharp right turns before landing on the Kowloon Bay runway of Kai Tak Airport within about 200 metres.

Soon after the 1983 Sino-British Agreement confirmed the handover of the whole of Hong Kong, including the leased New Territories, to China, a decision was made by the Hong Kong Government in April $1986^{6}$ to clear and resettle all owners and tenants of the KWC in private and public housing units.

In economic theory, land resources without de jure enforceable property rights are attract rent dissipation and a system of "might makes right" may emerge to constrain such dissipation under a situation of unclear property rights. Interestingly, however, although competition for land became keener over time due to Hong Kong's economic and population growth, there is no evidence that violence was involved in the development and sale of property units within the KWC. Developers made share contracts with the de facto unit/site owners to replace two to three-storey low-rise housing with 12 to 13 -storey blocks of flats. Upon completion, the units in the lower 4-5 storeys were given to the original occupants, while the upper units were sold. These units were, on average, 300-400 square feet each.

Under Hong Kong law, as the residential units were not erected on land leased from the Crown or built with building permits, they were illegal structures and, hence, the contracts for the aforementioned transactions were not enforceable in court due to their illegality. Nor could any written document concerning the sale and purchase of a unit be registered by the Land Registry.

However, most buyers preferred that the seller write a "contract" which is legally speaking a receipt of purchase with an express guarantee that the seller would bear liability for

\footnotetext{
${ }^{6}$ Jones (2011: pp.272-275). Surely this decision could not be unilaterally made by the Colonial regime or Britain and the blessing China was essential (Liu 2005: p.44)
} 
any dispute concerning the transfer of "title" to the buyer. A sample the authors inspected states that the seller disclaimed liability in case the property became subject to government demolition as "the will of Heaven" (an act of God). In inked Chinese calligraphy, such a document gave essential details of the parties, the sale date, the location of the unit sold, its sale price, and the names of the drafter and a witness.

More interestingly, initially such contracts were often stamped by the government's Inland Revenue Department (see Figure 1), but as soon as the Kaifong Association was established, its stamp replaced the government stamp (Figure 2). The Kaifong Association levied a witnessing fee and recorded each transaction for which its witnessing was requested in a logbook.

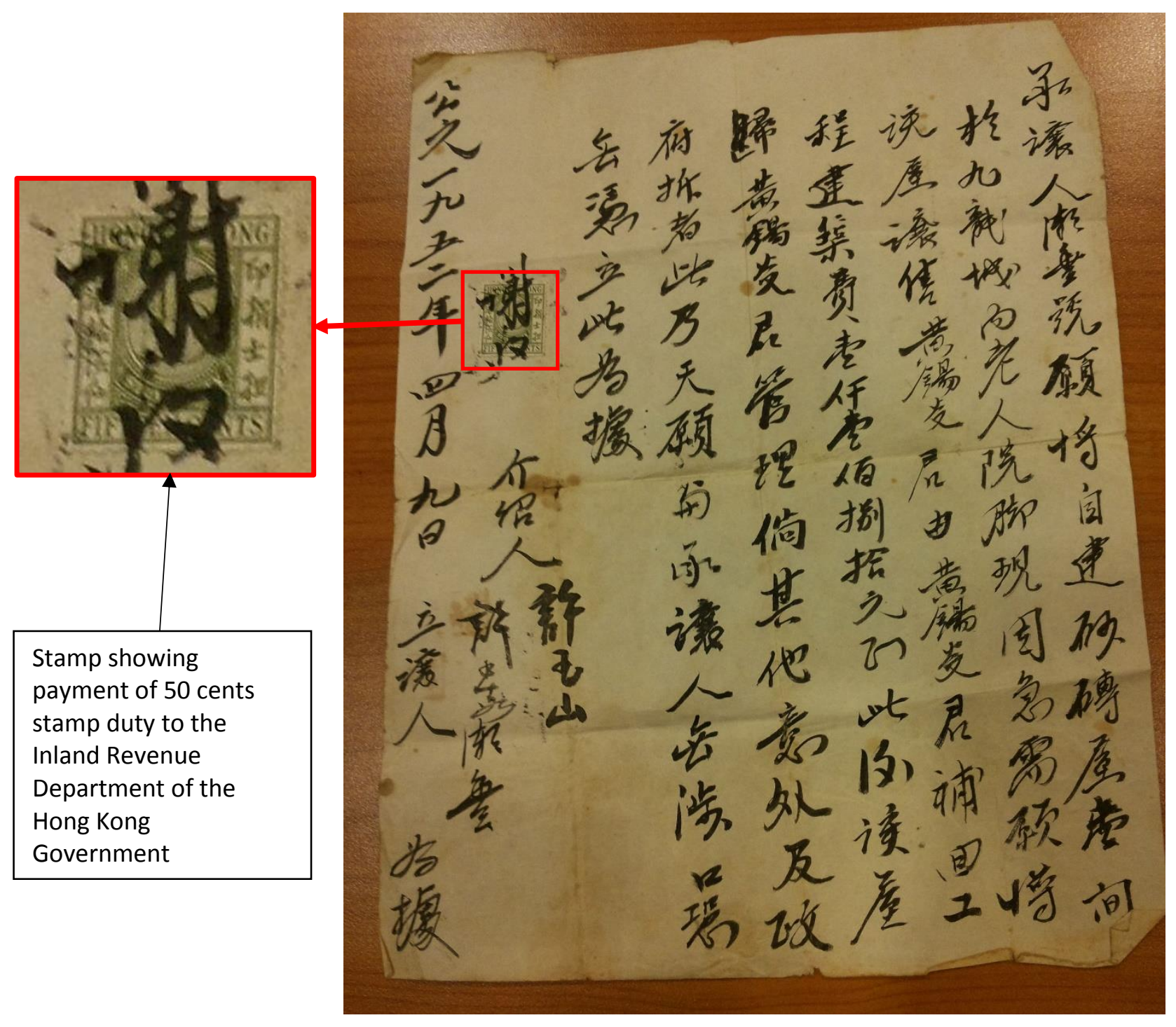

Figure 1: Sales and purchase contract of a property in the Kowloon Walled City signed on 9 April 1952 


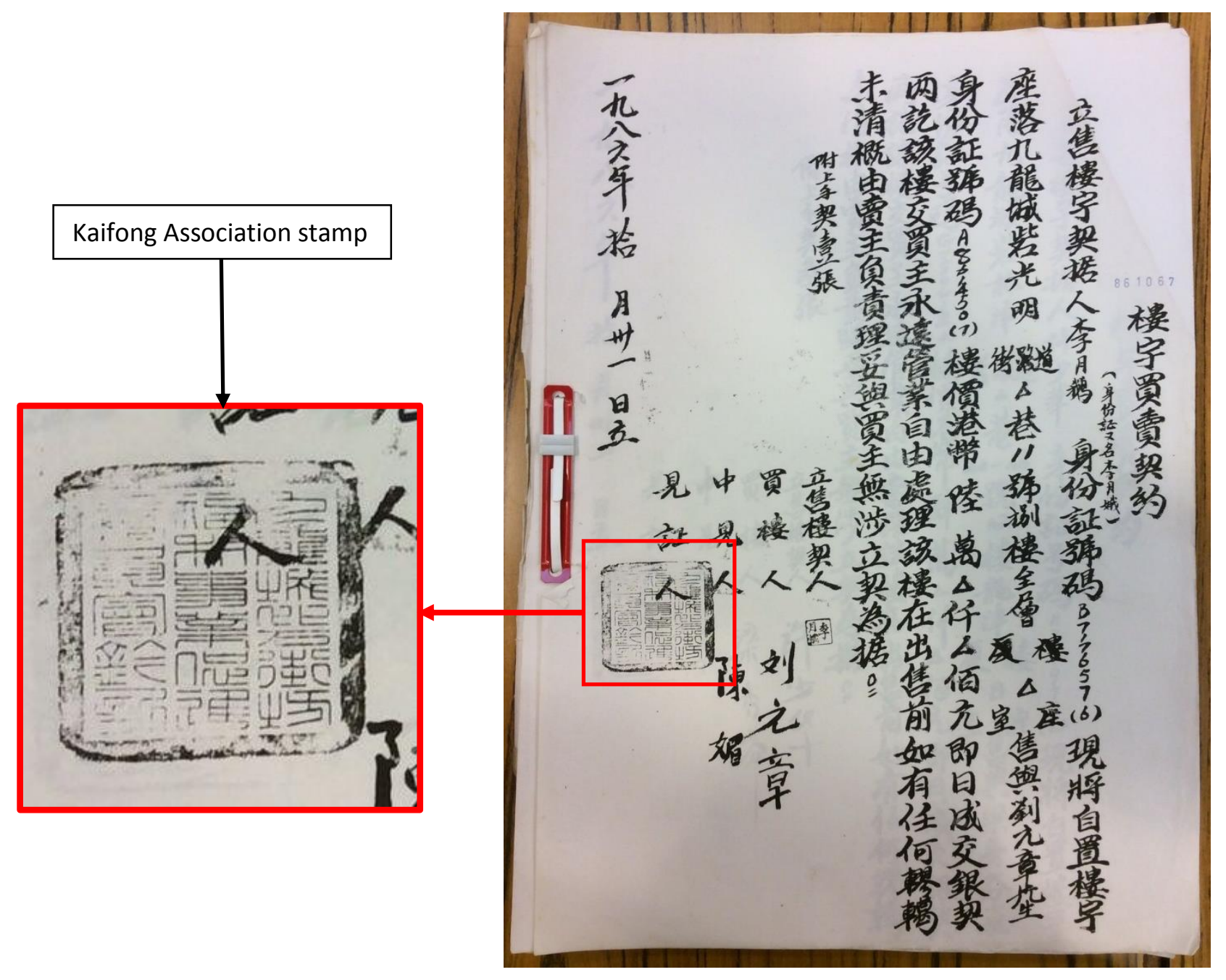

Figure 2: Sales and purchase contract of a property in the Kowloon Walled City signed on 31 October 1986, which shows a Kaifong Association stamp

Above all, when the colonial government sought to clear the KWC to build a garden, all those whom it denied as "property owners" were compensated well enough to buy "home ownership scheme" (HOS) housing units, while tenants were compensated with subsidized rent public housing units nearby. The presence of the official seal of the Kaifong Association was good evidence that an occupant was the owner of a premise under the clearance programme. 
Also, the government granted a plot of riparian land rights next to the Wong Tai Sin Police Station to the Kaifong Association, put into proper legal standing as the "Kowloon Walled City Kaifong Welfare Continual Promotion Association, Ltd.," to build, at its own cost, a twostorey activity centre.

\section{Questions and a conjecture}

A number of questions that pertain to property rights and witnessing can be raised over property transactions in the KWC.

First, why should the buyers and sellers of landed property bother to compile written records of their deals? Following standard legal teaching, these documents are of value to protect the buyer against anyone in "the rest of the world" to claim rights to a property. That a property is a squatter structure does not alter the usefulness of some evidence in writing as to the existence of and parties to the transaction, although there would not be any legal remedy in a Hong Kong common law court. This is so, as humans do not resort to conflict without some sort of justification, especially in Chinese society, in which a written agreement with the names of parties and witnesses always carry a great moral legitimacy. Scholars have found that in 1881 BC in the Middle East Chianu (1992) and in Medieval Islamic world (Harbord 2006; Greif 2012), witnesses were critical in enforcing private contracts in the absence of state courts.

The second and more curious question is why witnessing by the Kaifong Association became a practice. There was no evidence that this body compelled any one to join it or use any of its services. However, one may infer that developers supported it and that it was certainly treated by the colonial administration as a "major stakeholder" in the modern vernacular or as a "pressure group" (in the local political language at the time) whose position could not be ignored. The Kaifong Association was described in the confidential correspondence during the Cold War as "a mixed bag of landlords, gambling operations and left-wing sympathisers,"7 "communist," 8 and later "left-wing" and, in all cases, connected to the "CPG," which stood for the Chinese "Communist Party Government" of the People's Republic of China (China) run by the Chinese

\footnotetext{
7 See Paragraph 10, in Defence Branch, Colonial Secretariat (1972). "Paper for the Governor Committee: Multistorey Buildings on the Periphery of the Kowloon Walled City." Confidential paper in Confidential File CR5/3371/60 Part VII. [HKRS 163-9-233 Part I] This document could only be released on or after 2 February 2003 under the thirty-year rule.

8 See Paragraph 2 in draft dated 11.7.1972 at float to Colonial Secretary (1976). "Kowloon Walled City: Implementation of Ad Hoc Committee Reports." Confidential File CR5/3371/60 Part VII. [HKRS 163-9-233 Part I] This document could only be released on or after 2 February 2003 under the thirty-year rule.

${ }^{9}$ See Paragraph 2 in City District Officer (Kowloon City) (1975a). "Hong Kong Airport (Control of Obstructions) Ordinance: Development of No.24 Tung Tau Tsuen Road, Kowloon City." Confidential memo to Secretary for Security dated 27 May 1975. [HKRS No 396] This document could only be released on or after 6 January 2006 under the thirty-year rule.
} 
Communist Party (CCP). Any government demolition of a new building structure that exceeded the airport height restriction limit was executed only when it was clear that the Kaifong Association did not object. However, there was no evidence that the Kai Fong Association posed as a local Chinese government administering the KWC and compelled sellers to issue written receipts that it witnessed.

Therefore, a very probable answer is that the Kaifong Association's witnessing service was a voluntary one requested by the buyer on the advice of the developer in marketing its units. The developer gave such advice in case the government attempted to intervene by, say, threatening to clear the building in question, in which case the Kaifong Association could make a political representation to CPG to safeguard their property. Second-hand buyers follow such an established practice. In other words, the witnessing service was tied in with redevelopment and generated a rights creation process that transformed squatters' possessory interests acquired by physical occupation and acquiesced to by the colonial administration under its "blind eye" policy into one which signifies "security of tenure on Chinese territory". The colonial government monitored the activities closely and found that the witnessing service attracted a "handsome return". 10

Note that witnessing by a person reduces the transaction costs of dispute resolution to the extent that the person is alive and willing to appear before the contesting parties and a credible adjudicator. In time, a personal witness makes a diminishing, if any, contribution due to aging, emigration, or death. The value of a public land registry can overcome this problem by serving as a kind of witness under the doctrine of constructive immortality. Although the Kaifong Association, formed in "Chinese territory" by Hong Kong people, was not an official land registry, it played the role of a credible corporal witness and recorded transaction dates. By what theorists called a process of "informal formalization" (Benjaminsen et al. 2008; Colin 2013), the Kaifong Association gained what Ho (2006) called "institutional credibility".

A recent paper advanced the information-centred thesis that although "the state is generally unfit to make business innovations, it does have special advantages in accessing information due to its sovereign power in relation to taxation" (Lai et al. 2014: p.227). In this case, though the Kaifong Association did not tax, it did gather a pool of information on property titles that were disputed by the colonial administration. This systematic alignment of rights, when the time was ripe in 1983, rendered it a quasi-government registrar, as the original landlord

${ }^{10}$ See Paragraph 5(a) in City District Officer (Kowloon City) (1975a). "Hong Kong Airport (Control of Obstructions) Ordinance: Development of No.24 Tung Tau Tsuen Road, Kowloon City." Confidential memo to Secretary for Security dated 27 May 1975. [HKRS No 396] This document could only be released on or after 6 January 2006 under the thirty-year rule. 
that was expelled in May 1899 reclaimed not just the KWC and New Territories, but the whole of Hong Kong.

\section{Role of Registration in Terms of Property Rights}

From a property rights consideration, it can therefore be reasonably postulated, in light of the above analysis, that registration with the pro-PRC Kaifong Association served two functions:

(a) a kind of legal/moral insurance/defence vs. disputes by a third party over the title to a particular unit and

(b) a kind of political insurance or defence against disputes by the colonial government over ownership of any and all units in the KWC.

The first function was purely economic and applied to all squatter settlements. The Kaifong Association was definitely not a rent-seeking or pressure group. It contributed to wealth creation by enforcing contracts and lowering transaction costs in the $\mathrm{KWC}$, where property rights were uncertain or unclearly defined. China has a long tradition of using witnesses (individuals such as neighbours or respected authoritative figures like village heads) to define, clarify, and enforce property rights, particularly those over fixed assets such as land or landed properties. Even in China today, when no formal record exists, witnesses are used to affirm ownership and define rural land (e.g. forest) boundaries when land is transacted (Lai, Chau and Lorne 2015).

In terms of theory, Cheung's thesis of minimizing rent dissipation by creating an institution is relevant here. After 1945, the KWC began to operate in an almost anarchic situation to earn the local description of an area "ungoverned by three" regimes, namely the British, Chinese, and colonial governments. There were political constraints on the part of both the British and Chinese Governments to impose de jure rules or laws there. An anarchic situation means uncertain property rights, which tends to lead to rent dissipation. According to Cheung (1972, 2014), institutions will naturally merge to minimize rent dissipation. He also said that the transaction cost of the [merger and operation] of the observed institution would be the same as the dissipated rent (which was consistent with Neoclassical thinking). Cheung's idea is empirically real, as evidenced in a study by Nkurunziza (2007), who wrote that there was "a growing consensus in research that informal settlements are not as chaotic as often portrayed. The processes through which households in these settlements access housing land are not anarchic, but are structured and regulated by some form of social ordering."

The operation of private property rights requires a proof of asset ownership. For immobile physical properties, a witness is a low-cost means to prove ownership, while possession, rather than a witness, is normally a common means to prove ownership of portable and homogeneous properties such as gold and bank notes. Written records or word of mouth is 
a means to extend proof of ownership beyond the life of a witness. The choice depends on people's confidence in the witness and/or in the written record and subsequent enforcement costs. Transaction costs are lower if people have confidence in the system. This is independent of the rule of law/legal system. In fact, legal systems emerged to increase people's confidence and lower transaction costs. Even without any Western style legal system (or when the system does not function properly), people can still develop confidence in witnesses/records. Two examples are an authoritative witness and a recordkeeping organization. Either is considered authoritative if (in the case of the witness) s/he is a leader (such as village head), knowledgeable about ownership (neighbor), or (in the case of the organization) a powerful institution (e.g. a triad society). Familiarity with a system and its track record is also important. This make the emergence of institutions path-dependent. The initial system has first mover advantage over other systems.

When the Kaifong Association system emerged, it appeared to have a CCP background and, thus, was perceived as authoritative in the KWC (i.e., it attracted high confidence). As mentioned earlier, the colonial government monitored and researched the system and was happy to "turn a blind eye" on its operations, since riots in the KWC could get out of hand, but feared that it could become an excuse for the Chinese Government to send troops to Hong Kong "to restore peace". That the colonial government consulted the Kaifong Association further increased property buyers' confidence. Once the kaifong system operated for some time without any major problem, inertia developed and good will grew. Property owners' entitlement to compensation due to the KWC's demolition relied on the presentation of documents that were witnessed by the Kaifong Association and its records. This suggested that the colonial government did not ignore the system. In fact, it treated the Kaifong Association's records as valid and the level of compensation was based on consultation with the Kaifong Association.

Proof of ownership can be easier in a very congested environment, where neighbours know each other well. Occupation is another strong proof of ownership. If this is the case, renting units to strangers should not have been common in the KWC.

The second function was essential in the context of the de jure constitutional status of the KWC, which was contested by two sovereign bodies: the UK and China. The latter always saw the KWC as Chinese territory, whereas the UK held that it was part of the colony until June 1997. Those moving into the KWC accepted the risk of clearance by the colonial government, but such a risk diminished over time. Collectively refusing to yield to the colonial administration by claiming they were bona fide proprietors on Chinese soil instead of squatters on British-leased territory, KWC residents eschewed the potential benefit of secure low cost public housing for the potential benefit of securing, at lower market values, de jure private property rights within the KWC after 1997, when the New Territories reverted to China - assuming that China no longer disallowed private property by that time. 
As the witnessing and informal registration is, in itself, a useful service and all sober Hong Kong people knew that at least the New Territories were definitely "borrowed land on borrowed time," it is incorrect to categorize the Kaifong Association as a mere rent-seeker. Rather it helped transform the economic need for Function (a) into a rights creation process. Britain lost all of Hong Kong, but managed to implement her slum clearance-public garden scheme contemplated for the KWC starting in 1934. The Kaifong Association did not play a Schumpeterian innovative role to achieve a sustainable KWC by transforming it in-situ into a decent private high-rise property development for its proprietors. However, though eventually all privately-built post-war properties were demolished prior to 1997, all proprietors received compensation that enabled them to become bona fide private property owners and the Kaifong Association secured a permanent private site to continue its role as a cultural heritage promoter under the so-called one country-two systems political, economic, and legal institutional arrangement for post-1997 Hong Kong.

\section{Evidence of Property Rights Protection and Rent Dissipation}

Some empirical evidence can be found to support the idea that the property rights of the proprietors were protected and rent dissipation was constrained when the KWC was transformed into a high-rise settlement from the early 1970s.

Regarding property rights protection, it was found from recently disclosed post-war colonial government files that the state wanted and planned to clear all squatters. "The longterm aim has always been the clearance and redevelopment of the Walled City itself...the ultimate goal of Government should remain the complete clearance and redevelopment of the Walled City itself' (Colonial Secretariat 1969: paras 2 and 3). The resistance of the KWC residents, represented to China by the Kaifong Association, however, forced the colonial regime to accept the "political status quo," which stated that the KWC "should not be disturbed". However, the colonial government continued to contain the spread of the KWC mode of development within the formerly walled area with a so-called "Nunnery Scheme," which aimed to clear the four areas (coded name A, B, C, and D) surrounding the KWC, build/widen roads, and develop the areas for public housing. Area D became Mei Tung Estate. The developmental affairs of the KWC and a "sensitive zone" along its eastern periphery were, by and large, autonomous under the close eye policy. An officer of the colonial government expressed the wishful thinking that, D having been accomplished, the Scheme formed "a cordon insanitaire" around three sides of the Walled City" (Colonial Secretary 1976: Minute 9 dated 21 June 1972) AND the public (including residents of the KWC), upon the completion of the Nunnery Scheme, would demand that the government intervene to remove it as a source of negative externalities. 
The rationale was that the KWC would become "an isolated slum, surrounded by modern buildings" (Colonial Secretary 1976: para 4, draft paper at float, underlining authors').

The reality was that the Nunnery Scheme did not materialize beyond D and the isolated slum increased in height upon is redevelopment, which suggested that there was market demand for dwellings in KWC. Two questions on rent dissipation are worth asking. First, would the redevelopment be a scenario of complete chaos and dictated by might? Second, would living conditions deteriorate due to redevelopment?

Regarding the first question, a preliminary analysis of aerial photos and survey maps was done. Figures 3 to 6 show the KWC's property boundaries from 1922 to 1984 in relation to the lot boundaries of 1909. From these, it can be established that, amazingly, the property boundaries of the high-rise "slum" respected previous boundaries, while variation with the pre-war property boundaries was insignificant. Property redevelopment was orderly, which was strong evidence against an imagined scenario of chaos. From the confidential files inspected, there was no report of violent incidents during the land assembly process and a picture of peaceful contracting prevailed.

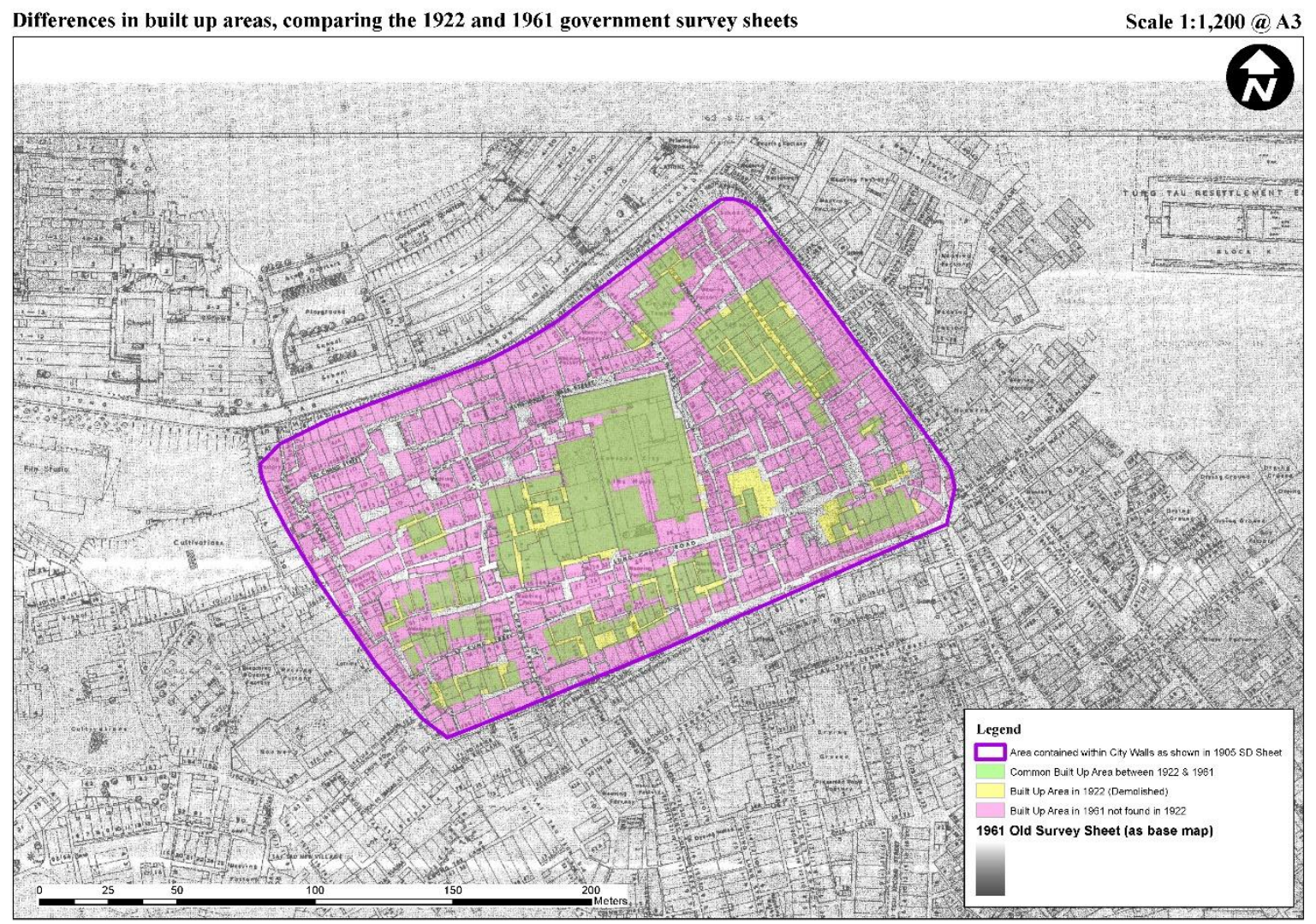

Figures 3: Comparison of the 1922 and 1961 survey map. 


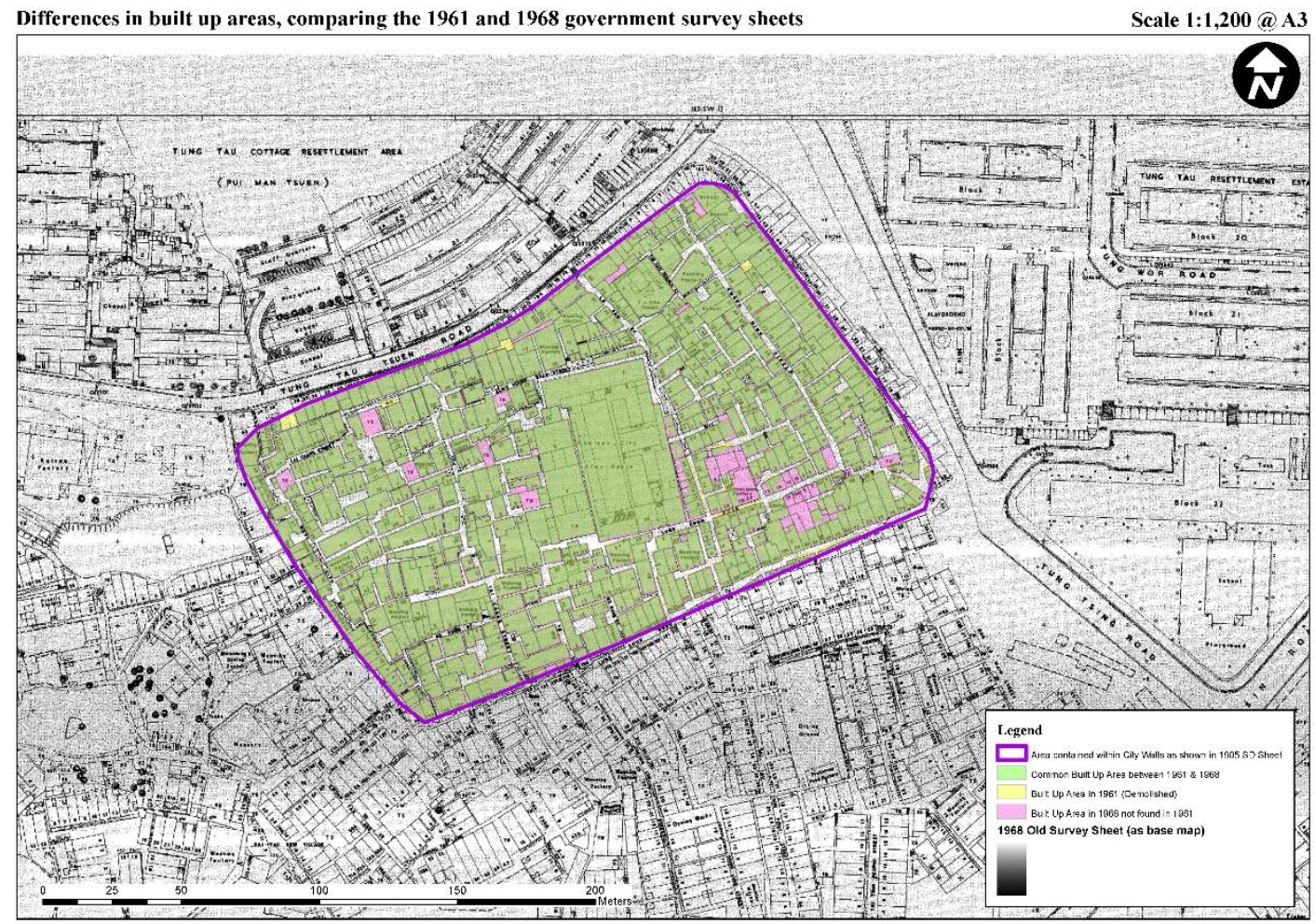

Figures 4: Comparison of the 1961 and 1968 survey map.

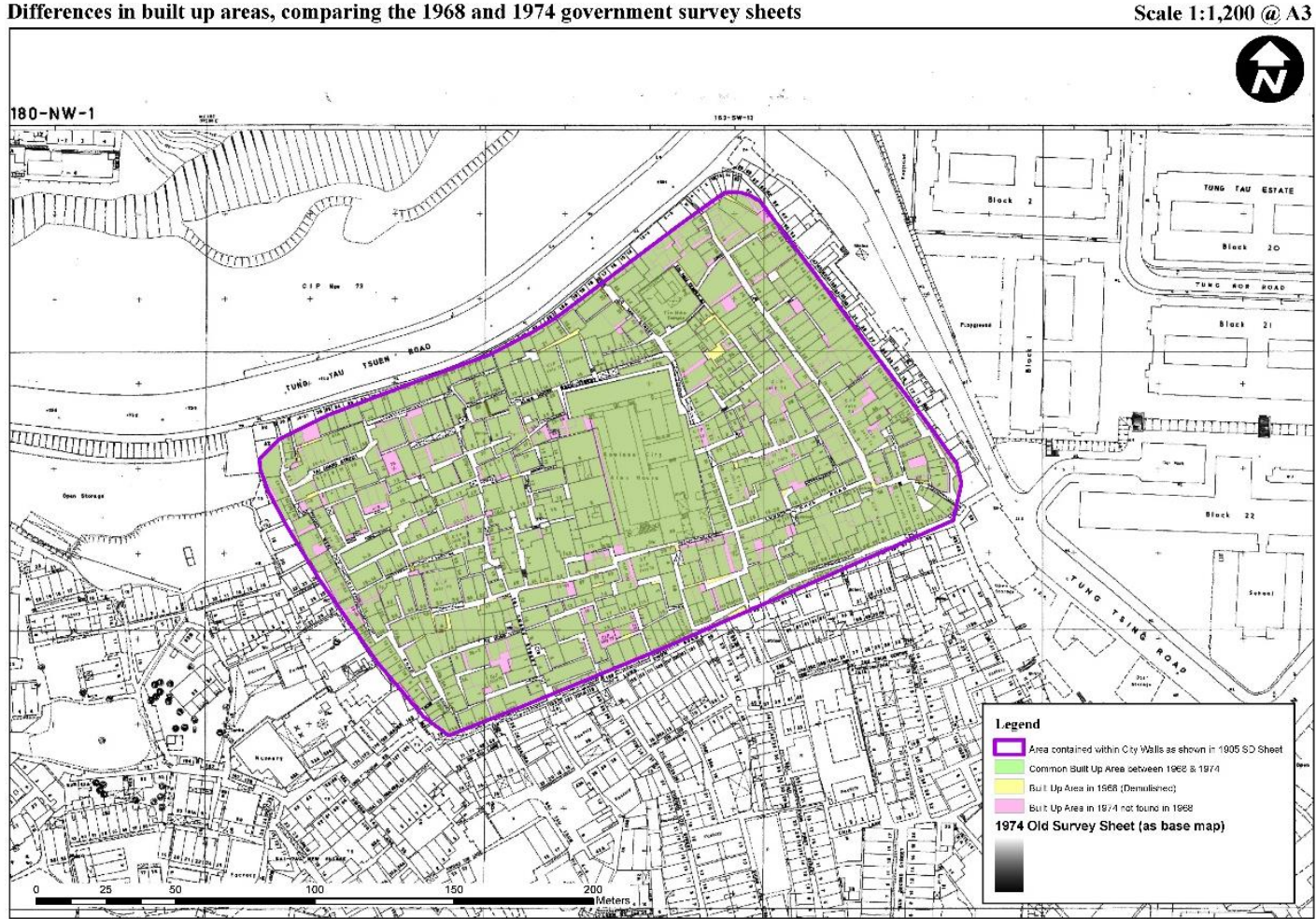

Figures 5: Comparison of the 1968 and 1974 survey map. 


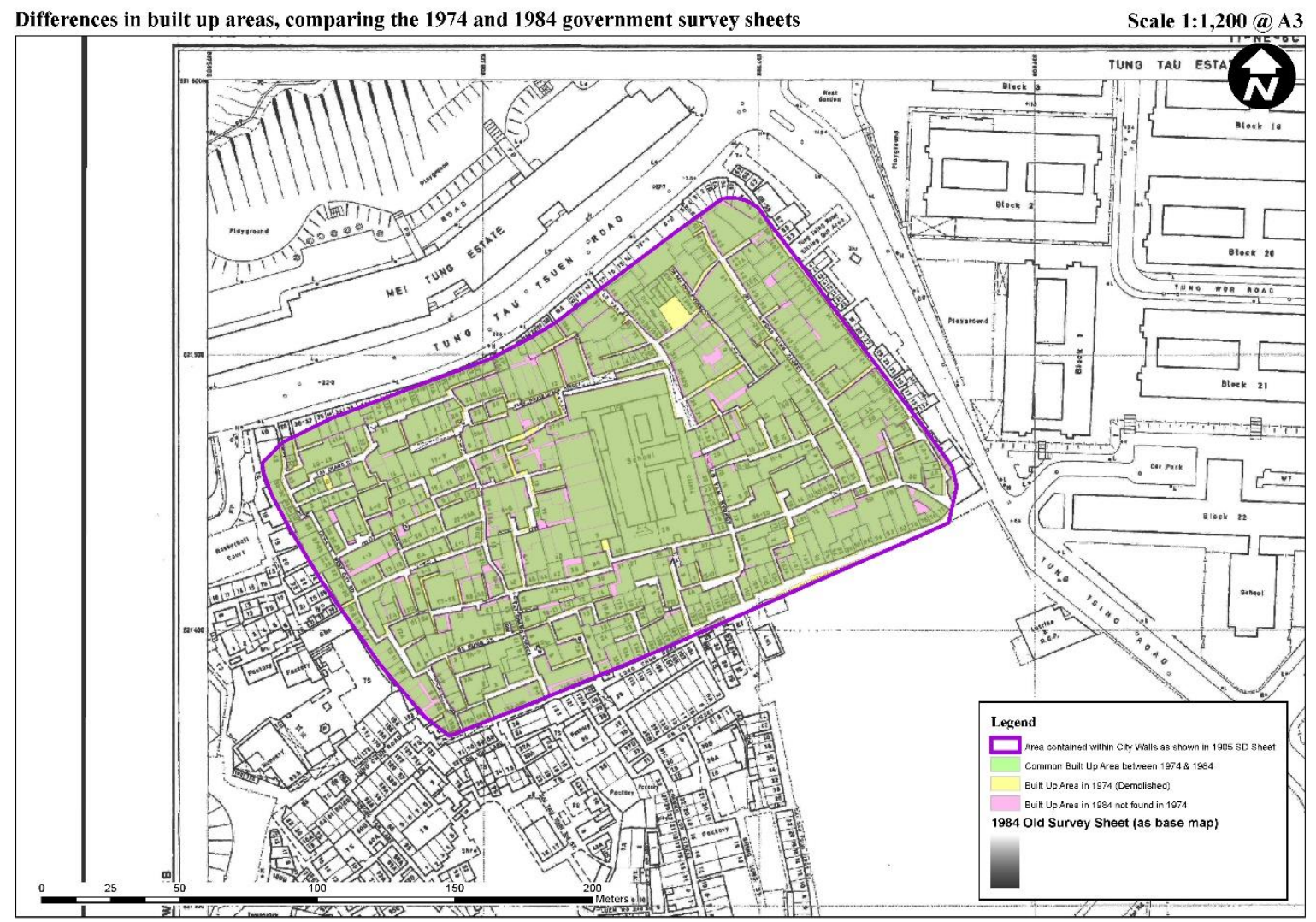

Figures 6: Comparison of the 1974 and 1984 survey map.

Second, the official records for the KWC's actual population indicated that it did NOT grow much over the years. As mentioned, Jones (2011) gave a 1987 figure of 33,000. Note, however, that this population was more or less the same as an official estimate of 28,000-35,000 in 1972 City District Officer (Kowloon City) (1972). The message is: the overall density of the KWC did not increase, but building heights grew from 2 to 10-13. This meant that population density per flat actually fell upon redevelopment. No record of disease outbreaks, major fires, or building collapses was reported.

In terms of town scape, the external façade of the KWC before demolition was, more or less, the same as any contemporary private redevelopment outside the KWC (Figure 7 shows a 2015 photo of a building group that looks like the KWC Figure 8). The KWC was physically inferior to lawful development outside it in terms of the narrowness of the public entrances on the ground, which limited sunlight penetration and made local water supply from artesian wells unstable. Otherwise, life inside was far better than has been depicted. 


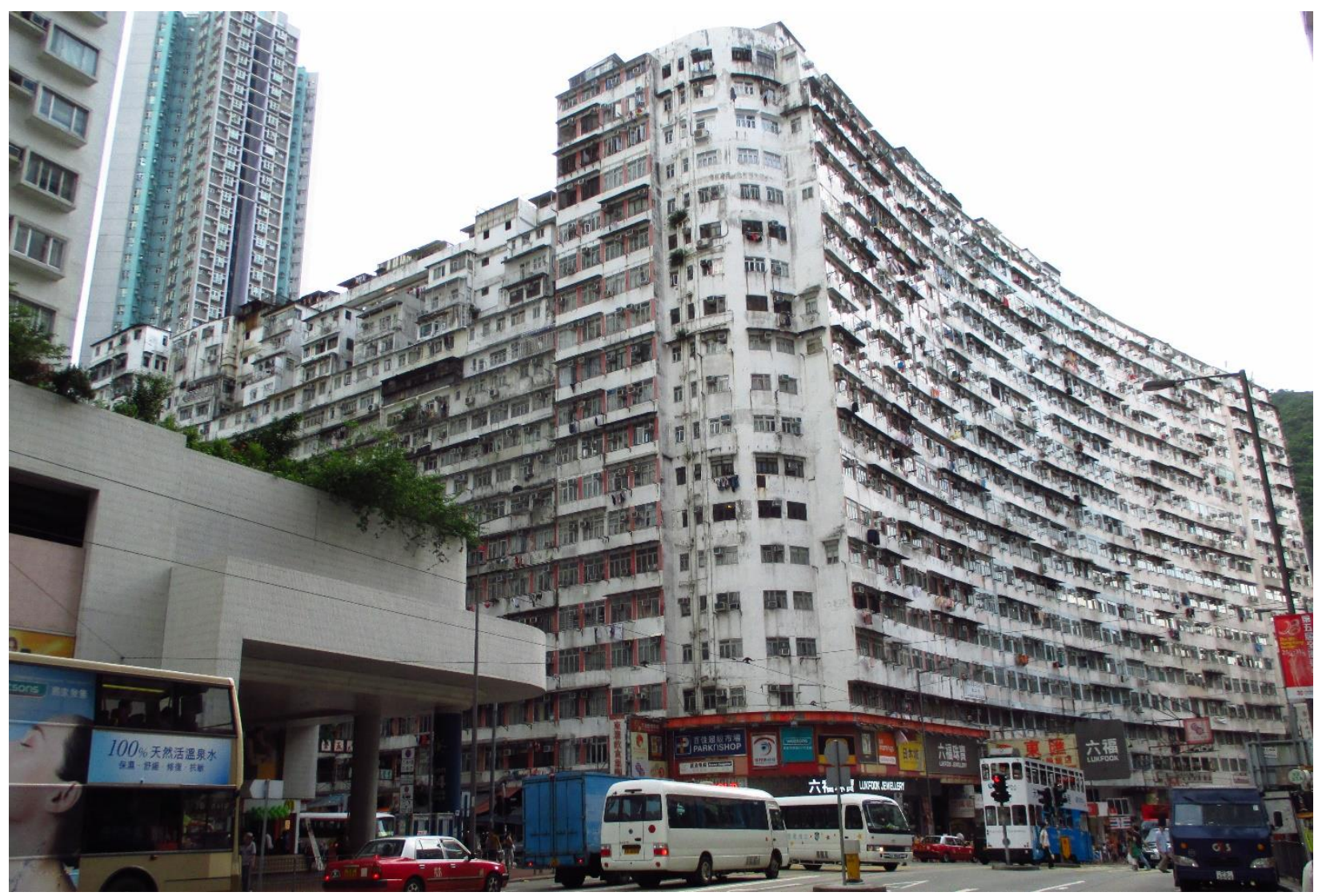

Figures 7: Photo a building group in Hong Kong taken on 2 June 2015. 


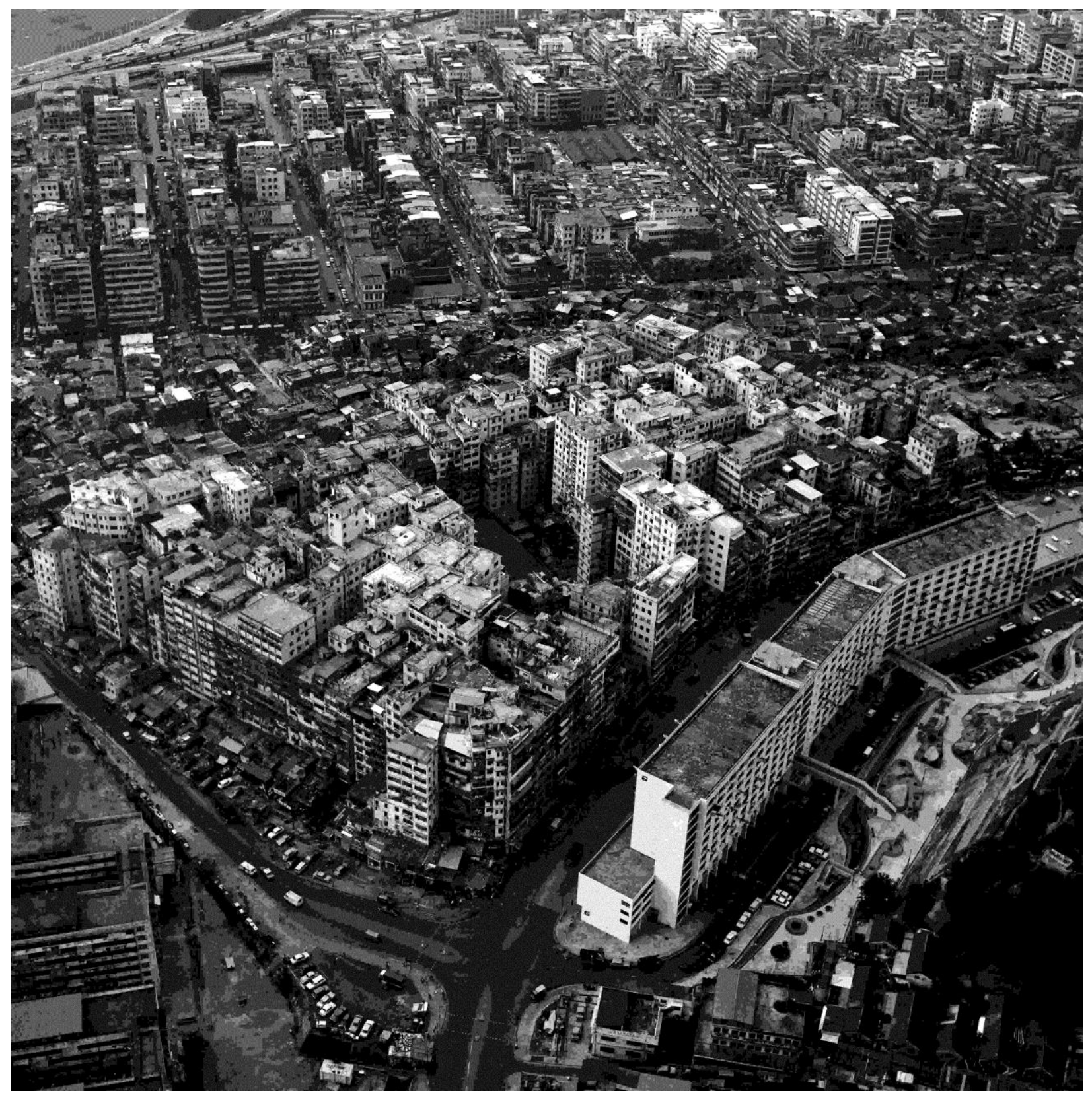

Figures 8: Photo the Kowloon Walled City taken in 1976. 
KWC developers did make some innovations. There was a building law to provide a lift for any building that exceeded seven storeys. Therefore, many private buildings only had seven storeys. Four lifts were actually built by developers at the key corners of the KWC and the floors of its tightly-packed buildings were linked by public corridors at various levels. These lifts and corridors were public goods privately provided for easy access and fire escapes which consumers wanted, even though the developers were not bound to build them. The Kaifong Association regularly maintained them and added garbage disposal as a communal service. Note that the number of builders was not perfectly competitive as a scenario of anarchy entails. Confidential government files showed that building supply was oligarchic, involving a total of ten firms with 5 most dominating, suggesting the existence of an order of some form.

\section{Discussion and conclusion}

The KWC was a good example of Hong Kong people ruling Hong Kong in the sense that it was a manifestation of the power of freedom of contract by local Chinese people under various institutional constraints. The KWC was not anarcho-autarchic, however. It interacted with the rest of Hong Kong politically with some form of representation and economically under the freedom of contract. Though the Kaifong Association was not a recognized local government, it was pivotal in protecting the rights of property owners inside the KWC and along the "sensitive zone". Resistance to further encroachment and incursion by the colonial government succeeded - the consolidation of the "sensitive zone" and the shelving of the "Nunnery Scheme" all testify to the political and economic significance of the Kaifong Association. Environmental degradation was limited in the high-rise development: no building collapsed; no major fire or plague broke out; and population density did not increase. Viewed in this light, the witnessing of contracts of property sales must have been key to constraining rent dissipation and conferring property rights. Developers made innovations and provided an acceptable standard of public services in the absence of building controls for a high-rise settlement.

It traded freely with the rest of the world. It exported a lot of goods (especially foodstuff like fish balls and noodles) and services (dental and medical) and imported electricity and some government services like postal and police services. One important import was building construction, the transaction costs for which was much reduced by the witnessing of contracts by the Kaifong Association. The Association is a special form of club that, unlike formal modern resident associations, does not involve great transaction costs of incorporation or dissolution. This means that it may be weaker in governance, but stronger in community building, which may not be best promoted by elaborated ex ante contractual rules. 
This unique settlement cannot be considered sustainable, as it did not only violate many social and environmental concerns, but also failed to convey a proper historic or cultural heritage message of the place. No one would endorse this as a role model for development for the rest of Hong Kong. This notwithstanding, an important policy implication can be grasped: freedom of association for collective welfare is desirable and in line with the principle of subsidiarity, which is predicated on respect for human dignity. The state should collaborate with, rather than repress, these resident associations and welcome them as a bridge of communication with the individuals, families, and business enterprises they represent. One very critical aspect of the public goods that these associations supply is its reliable contract witnessing power, which should be recognised as quasi-judicial by policy makers in land development.

\section{Acknowledgements}

The authors would like to thank Mr. Mark Hansley Chua and Miss Maria Yu for their archive research on PRO materials; the Kowloon Walled City Kaifong Welfare Promotion Association for allowing them to inspect property sale contracts they keep; and the Government Information Service of the Hong Jong Special Administrative Region Government for permission to reproduce Figure 8 . 


\section{$\underline{\text { References }}$}

Abdulai, R.T., Hammond, F.N., 2010. Landed property market information management and access to finance. Prop. Manag. 28(4), 228-244.

Abdulai, R.T., Owusu-Ansah, A., 2014. Land information management and landed property ownership security: Evidence from state-sponsored court system. Habitat Int. 42(April), 131-137.

André, C., Platteau, J.P., 1998. Land relations under unbearable stress: Rwanda caught in the Malthusian trap. J. Econ. Behav. Organ. 34(1), 1-47.

Arruñada, B., 2003. Property enforcement as organized consent. J. Law Econ. Organ. 19(2), 401444.

Benjaminsen, T.A., Holden, S., Lund, C., Sjaastad, E., 2009. Formalisation of land rights: Some empirical evidence from Mali, Niger and South Africa. Land Use Policy. 26(1), 28-35.

Bezu, S., Holden, S., 2014. Demand for second-stage land certification in Ethiopia: Evidence from household panel data. Land Use Policy. 41, 193-205.

Blocher, J., 2006. Building on custom: land tenure policy and economic development in Ghana. Yale Hum. Rights Dev. Law J. 9, 177-202.

Bristow, M.R., 1984. Land-use planning in Hong Kong: history, policies and procedures. Oxford University Press.

Brown, J., 2003. Rural women's land rights in Java, Indonesia: strengthened by family law, but weakened by land registration. Pac. Rim L. Policy J. 12(3), 631-651.

Çağdaş, V., Stubkjær, E., 2009. Doctoral research on cadastral development. Land Use Policy. 26(4), 869-889.

Caplan, B., 1997. The Economics of Non-State Legal Systems, Legal Notes No. 26. Libertarian Alliance, London.

Cheung, S.N.S., 1974. Theory of Price Control, A. Journal of Law and Economics 17(1), 53-71.

Cheung, S.N.S., 2014. The Economic System of China. Man and the Econ. 1(1), 1-49.

Chhetri, R.B., 2014. Land Policy Instruments in Nepal. J. Inst. Eng. 10(1), 69-79.

Chianu, E., 1992. Priorities under the Land Registration Act in Nigeria. J. Afr. Law 36(1), 66-80.

City District Officer (Kowloon City), 1972. "A Short Study on Multi Storey Buildings in and Around the Walled City." Confidential report dated 7.11. 1972 in Colonial Secretary (1976). 
"Kowloon Walled City: Implementation of Ad Hoc Committee Reports" Confidential File CR5/3371/60 Part VII, HKRS 163-9-233 Part II.

City District Officer (Kowloon City), 1975a. "Hong Kong Airport (Control of Obstructions) Ordinance: Development of No.24 Tung Tau Tsuen Road, Kowloon City.” Confidential memo to Secretary for Security dated 27 May 1975, HKRS No.396.

City District Officer (Kowloon City), 1975b. "Kowloon Walled City: Occupied Buildings Exceeding Height Limits," confidential paper dated 16 October 1975, HKRS No.396.

Colin, J.-P., 2013. Securing rural land transactions in Africa. An Ivorian perspective. Land Use Policy. 31, 430-440.

Colonial Secretariat, 1969. "Kowloon Walled City and Adjoining Areas" Confidential memo to various parties, (62) in Temp SCR 31/69 dated 19 September 1969.

Colonial Secretary, 1976. "Kowloon Walled City: Implementation of Ad Hoc Committee Reports" Confidential File CR5/3371/60 Part VII, HKRS 163-9-233 Part I.

Defence Branch Colonial Secretariat, 1972. "Paper for the Governor Committee: Multi-storey buildings on the Periphery of the Kowloon Walled City." Confidential paper in Confidential File CR5/3371/60 Part VII, HKRS 163-9-233 Part I.

Degolyer, M.E., Scott, J.L., 1996. The myth of political apathy in Hong Kong. Ann. Am. Acad. Political Soc. Sci. 547(1), 68-78.

Delville, P.L., 2002. When Farmers use 'Pieces of Paper' to record their land transactions in Francophone Rural Africa: Insights into the Dynamics of Institutional Innovation. Eur. J. Dev. Res. 14(2), 89-108.

Fandl, K.J., 2005. Dead Capital and the Sea: Post-Tsunami Relief for the Southeast Asian Informal Economy. Yale J. Int. Aff. 1(1), 79-88.

Friedman, D.D., 2005. From Imperial China to cyberspace: Contracting without the state. J. Law Econ. \& Policy. 1(2), 349-370.

Fung, P.S.-S., Lee, A.S.-M., 2014. History of Land Registration and Small House Policies in the New Territories of the Hong Kong Special Administrative Region, the People's Republic of China. LHI J. Land Hous. Urban Aff. 5(1), 53-56.

Girard, G., Lambot, I., Goddard, C., 1999. City of darkness: life in Kowloon Walled City. Watermark.

Glasze, G., 2005. Some reflections on the economic and political organisation of private neighbourhoods. Hous. Stud. 20(2), 221-233. 
Gough, K.V., Yankson, P.W.K., 2000. Land markets in African cities: the case of peri-urban Accra, Ghana. Urban Stud. 37(13), 2485-2500.

Greiber, T., 2011. Enabling conditions and complementary legislative tools for PES, in: Ottaviani, D., Scialabba, N.E.-H. (Eds.), Payments for Ecosystem Services and Food Security. Food and Agriculture Organization, Rome, pp. 205-240.

Greif, A., 2012. The Maghribi traders: a reappraisal? Econ. Hist. Rev. 65(2), 445-469.

Harbord, D., 2006. Enforcing cooperation among medieval merchants: The Maghribi traders revisited. MPRA Paper No. 1889, posted 24. February 2007 Online at http://mpra.ub.unimuenchen.de/1889/.

Hase, P.H., 2013. Custom, Land and Livelihood in Rural South China: The Traditional Land Law of Hong Kong's New Territories, 1750-1950. Hong Kong University Press.

Hayes, J.W., Hayes, J., 1983. Secular Non-gentry Leadership of Temple and Shrine Organizations in Urban British Hong Kong. J. Hong Kong Branch R. Asiatic Soc. 23, 113-136.

Ho, P., 2006. Credibility of institutions: forestry, social conflict and titling in China. Land Use Policy. 23(4), 588-603.

Innes, J.R., 1918. Land Law and Registration of Title in the Philippine Islands. J. Comp. Legis. Int. Law 18(2), 266-272.

Jones, G., 2011. The Kowloon City District and the Clearance of the Kowloon Walled City: Personal Recollections. J. R. Asiatic Soc. Hong Kong Branch, 257-278.

Kingston, L., 2013. An Evaluation of Environmental Education Programs on Pemba Island, Paper 1523. Independent Study Project (ISP) Collection.

Koczberski, G., Curry, G.N., Anjen, J., 2012. Changing land tenure and informal land markets in the oil palm frontier regions of Papua New Guinea: the challenge for land reform. Austr. Geogr. 43(2), 181-196.

Kowloon City District Council. The Kowloon City, Hong Kong: Man Lee Publishing, 2005 (Chinese publication).

Lai, L.W.C., 1996. Zoning and property rights. Hong Kong University Press, Hong Kong.

Lai, L.W.C., 1998. The leasehold system as a means of planning by contract: the case of Hong Kong. Town Plan. Rev. 69(3), 249-276.

Lai, L.W.C., 2015. "Where to draw the line?" That is a land use planning question for the land surveyor and the town planner. Land Use Policy. 42, 619-627. 
Lai, L.W.C., Chan, P.Y.L., 2004. The formation of owners' corporations in Hong Kong's private housing estates: A probit evaluation of Mancur Olson's group theory. Prop. Manag. 22(1), 55-68.

Lai, L.W.C., Chau, K.W., Lee, C.K., Lorne, F.T., 2014. The informational dimension of real estate development: A case of a "positive non-interventionist" application of the Coase Theorem. Land Use Policy. 41, 225-232.

Lai, L.W.C., Chau, K.W. and Lorne, F.T. (2015), “ 'Unclear' Initial Delineation of Property Boundaries and the Third Coase Theorem," Land Use Policy, in print.

Lai, L.W.C., Ho, D.C.W., Leung, H.F., 2010. Change in Use of Land: A Practical Guide to Development in Hong Kong, 2 ed. Hong Kong University Press, Hong Kong.

Lau, S.K., 1981. The government, intermediate organizations, and grass-roots politics in Hong Kong. Asian Survey, 865-884.

Liu, R., 2005. Jiulongcheng Qu feng wu zhi [Heritage of Kowloon City] (in Chinese). Kowloon City District Council, Hong Kong.

Lo, S.H., 1990. Political culture and participation in Macau. Asian Aff. Am. Rev. 17(3), 147-155.

Mackenzie, F., 1996. Conflicting Claims to Custom: Land and Law in Central Province, Kenya, 1912-52. J. Afr. Law 40(01), 62-77.

Manirakiza, J.G., 2014. The Role of Land Records in Supoort of Post-Conflict Land Administration: A Case Study of Rwanda in Gasabo District, Master of Science. Faculty of GeoInformation Science and Earth Observation. University of Twente.

Manzi, T., Smith-Bowers, B., 2005. Gated communities as club goods: segregation or social cohesion? Hous. Stud. 20(2), 345-359.

Meinzen-Dick, R., Gregorio, M.D., Dohrn, S., 2008. Decentralization, pro-poor land policies, and democratic governance. International Food Policy Research Institute (IFPRI).

Miners, N., 1981. The government and politics of Hong Kong. Oxford University Press.

Musembi, C.N., 2007. De Soto and land relations in rural Africa: breathing life into dead theories about property rights. Third World Q. 28(8), 1457-1478.

Nkurunziza, E., 2007. Informal mechanisms for accessing and securing urban land rights: the case of Kampala, Uganda. Environ. Urban. 19(2), 509-526.

Nwogugu, E., 1968. An Examination of the Position of Illiterates in Nigerian Law. J. Afr. Law 12(01), 32-55. 
Parsa, A., Nakendo, F., McCluskey, W.J., Page, M.W., 2011. Impact of formalisation of property rights in informal settlements: Evidence from Dar es Salaam city. Land Use Policy. 28(4), 695705.

Perera, T.G.U.P., 2011. Implementing Land Registration Systems in Sri Lanka, Being Pragmatic. Sri Lanka J. Real Estate 1(4), 74-96.

Popham, P., 1993. The city of darkness. Archit. Rev. 193(1161), 71-75.

Rawski, E.S., 1972. Agricultural change and the peasant economy of South China. Harvard University Press, Cambridge.

Rubin, P.H., 1994. Growing a legal system in the post-communist economies. Cornell Int. Law J. 27(1), 1 .

Siu-Kai, L., 1981. The government, intermediate organizations, and grass-roots politics in Hong Kong. Asian Surv. 21(8), 865-884.

Strathern, A.J., Stewart, P.J., 1998. Shifting Places, Contested Spaces: Land and Identity Politics in the Pacific. Austr. J. Anthropol. 9(1), 209-224.

Toulmin, C., 2009. Securing land and property rights in sub-Saharan Africa: the role of local institutions. Land Use Policy. 26(1), 10-19.

Wanjohi, M.W., 2007. Investigating the effects of property rights formalisation on property markets in informal settlements: The case of Dar es Salaam City, Tanzania, Master of Science. International Institute for Geo-Information Science and Earth Observation, Enschede, The Netherlands.

Wesley-Smith, P., 1973. Walled City of Kowloon: Historical and Legal Aspects, The. Hong Kong Law J. 3(1), 67-96.

Wong, A.K., 1971. Chinese voluntary associations in Southeast Asian cities and the Kaifongs in Hong Kong. J. Hong Kong Branch R. Asiatic Soc. 11, 62-73.

Yau, Y., 2013. Willingness to participate in collective action: The case of multiowned housing management. J. Urban Aff. 35(2), 153-171.

Yemadje, R.H., Crane, T.A., Vissoh, P.V., Mongbo, R.L., Richards, P., Kossou, D.K., Kuyper, T.W., 2012. The political ecology of land management in the oil palm based cropping system on the Adja plateau in Benin. NJAS-Wagening. J. Life Sci. 60(63), 91-99.

Zevenbergen, J., Augustinus, C., Antonio, D., Bennett, R., 2013. Pro-poor land administration: principles for recording the land rights of the underrepresented. Land Use Policy. 31, 595-604. 
